\title{
Impact of bundle for central line associated bloodstream infections prevention
}

\author{
RE Quirós*', L Fabbro, A Novau \\ From International Conference on Prevention \& Infection Control (ICPIC 2011) \\ Geneva, Switzerland. 29 June - 2 July 2011
}

\section{Introduction / objectives}

Bundles have been developed to facilitate the application of infection control guidelines. Because in our institution the rates of central line associated bloodstream infections (CL-BSI) were above the international standards it was decided to implement a specific bundle through a multimodal approach.

The aim of this study was to describe the strategy of bundle implementation for prevention of CL-BSI and to estimate their impact.

\section{Methods}

Since Mar'10 the following measures were implemented at the ICUs to prevent CL-BSI: use central venous catheters only if strictly necessary; avoiding the femoral site if possible; hand hygiene with alcohol-gel before insertion; using full-barrier precautions during the insertion of central venous catheters; cleaning the skin with chlorhexidine (2\%) and removing unnecessary catheters. The implementation was carried out through the model of "5Es" (Engage, Education, Execution, Evaluation and Encouragement). The rate of CL-BSI during the intervention period (Mar'10-Feb'11) was compared with the average of the 12 months prior to implementation. All costs are expressed in US dollars. For economic impact analysis an attributable cost of U\$S 5,500 was used.

\section{Results}

The incidence rate of CL-BSI at the baseline period was 6.84 events per \%o device-days in comparison with 2.70 events per \%o device-days during implementation period (RR 0.40; 95\% CI 0.22 to $0.69, \mathrm{p}<0,01$ ). There are no changes in the utilization ratio between both periods (0.45 [6429/14222] and 0.44 [7025/16077], respectively). During the implementation period the level of

Prevention and Infection Control Department, Hospital Universitario Austral, Pilar, Argentina

(c) 2011 Quirós et al; licensee BioMed Central Ltd. This is an open access article distributed under the terms of the Creative Commons Attribution License (http://creativecommons.org/licenses/by/2.0), which permits unrestricted use, distribution, and reproduction in any medium, provided the original work is properly cited. adherence rises to more than $90 \%$ in all bundle components. While the annual incremental cost to prevent CL-BSI was U\$S 28,300, the overall net savings was U\$S 130,500 .

\section{Conclusion}

The effective implementation of this bundle in our hospital reduced the CL-BSI with a significant net saving.

\section{Disclosure of interest}

None declared.

Published: 29 June 2011

doi:10.1186/1753-6561-5-S6-O11

Cite this article as: Quirós et al:: Impact of bundle for central line associated bloodstream infections prevention. BMC Proceedings 20115 (Suppl 6):011.

Submit your next manuscript to BioMed Central and take full advantage of:

- Convenient online submission

- Thorough peer review

- No space constraints or color figure charges

- Immediate publication on acceptance

- Inclusion in PubMed, CAS, Scopus and Google Scholar

- Research which is freely available for redistribution 